\title{
A Great Barrier Reef Sinularia sp. Yields Two New Cytotoxic Diterpenes
}

\section{Anthony D. Wright ${ }^{\dagger}$, Jonathan L. Nielson ${ }^{\star}$, Dianne M. Tapiolas, Catherine H. Liptrot ${ }^{\S}$ and Cherie A. Motti *}

Australian Institute of Marine Science, PMB no. 3, Townsville MC, Townsville, QLD 4810, Australia; E-Mails: adwright@hawaii.edu (A.D.W.); jonathon.nielson@acdlabs.com (J.L.N.);

d.tapiolas@aims.gov.au (D.M.T.); catherine.liptrot@jcu.edu.au (C.H.L.)

$\dagger$ Present address: College of Pharmacy, University of Hawaii, 34 Rainbow Drive, Hilo, HI 96720, USA.

* Present address: ACD Labs UK, Building A, Trinity Court, Wokingham Road, Bracknell, Berkshire RG42 1PL, UK.

$\S$ Present address: Advanced Analytical Centre, James Cook University, Townsville, QLD 4811, Australia.

* Author to whom correspondence should be addressed; E-Mail: c.motti@aims.gov.au; Tel.: +61-7-47534143; Fax: +61-7-47725852.

Received: 4 June 2012; in revised form: 25 June 2012 / Accepted: 23 July 2012 /

Published: 31 July 2012

Abstract: The methanol extract of a Sinularia sp., collected from Bowden Reef, Queensland, Australia, yielded ten natural products. These included the new nitrogenous diterpene $\left(4 R^{*}, 5 R^{*}, 9 S^{*}, 10 R^{*}, 11 Z\right)-4$-methoxy-9-((dimethylamino)-methyl)-12,15-epoxy-11 (13)-en-decahydronaphthalen-16-ol (1), and the new lobane, $\left(1 R^{*}, 2 R^{*}, 4 S^{*}, 15 E\right)$-loba-8,10, 13(14),15(16)-tetraen-17,18-diol-17-acetate (2). Also isolated were two known cembranes, sarcophytol-B and (1E,3E,7E)-11,12-epoxycembratrien-15-ol, and six known lobanes, loba-8, 10,13(15)-triene-16,17,18-triol, 14,18-epoxyloba-8,10,13(15)-trien-17-ol, lobatrientriol, lobatrienolide, 14,17-epoxyloba-8,10,13(15)-trien-18-ol-18-acetate and (17R)-loba-8,10,13 (15)-trien-17,18-diol. Structures of the new compounds were elucidated through interpretation of spectra obtained after extensive NMR and MS investigations and comparison with literature values. The tumour cell growth inhibition potential of 1 and 2 along with loba-8,10,13(15)-triene-16,17,18-triol, 14,17-epoxyloba-8,10,13 (15)-trien-18-ol-18-acetate, lobatrienolide, (1E,3E,7E)-11,12-epoxycembratrien-15-ol and sarcophytol-B were assessed against three human tumour cell lines (SF-268, MCF-7 and 
H460). The lobanes and cembranes tested demonstrated 50\% growth inhibition in the range 6.8-18.5 $\mu \mathrm{M}$, with no selectivity, whilst 1 was less active ( $\left.\mathrm{GI}_{50} 70-175 \mu \mathrm{M}\right)$.

Keywords: Sinularia; Alcyoniidae; anticancer activity; lobane; cembrane; diterpene

\section{Introduction}

There have been many reports documenting the diversity of secondary metabolites produced by soft corals from the genus Sinularia, including sesquiterpenes [1,2], diterpenes [3-7], cembranoids [8-11], polyhydroxylated steroids [12], glycosides [13], sphingosines [14], farnesyl quinols [15,16], and polyamines [17]. These metabolites have been shown to possess a range of biological activities including antimicrobial [5], antiviral [4], anti-inflammatory [4,11], cytotoxic [8-10,17], anticancer [3,18], antifouling [19], antifeedant [20], and allelopathic [21,22] activities. Given this wide-ranging diversity in chemical structure and biological activity, it is not surprising that soft corals, which do not have a hard calcareous skeleton, are relatively well defended against predation [20] and are effective competitors for space on coral reefs [21]. As a result, the Sinularia genus remains an attractive target for the discovery of novel bioactive metabolites.

As part of the biodiscovery program at the Australian Institute of Marine Science (AIMS), the ethanol (EtOH) extract of a Great Barrier Reef soft coral Sinularia sp., was determined to have significant activity in the NCI 60 cell line COMPARE analysis [23]. Based on this, the sample was selected for recollection, large scale extraction and workup. The methanol $(\mathrm{MeOH})$ extract of the recollected soft coral tissue was subjected to bioassay-guided fractionation, using $\mathrm{C} 18$ flash vacuum liquid chromatography and preparative C18 HPLC, to yield the new nitrogenous diterpene $\left(4 R^{*}, 5 R^{*}, 9 S^{*}, 10 R^{*}, 11 Z\right)$-4-methoxy-9-((dimethylamino)-methyl)-12,15-epoxy-11(13)-en-decahydron aphthalen-16-ol (1), the new lobane, $\left(1 R^{*}, 2 R^{*}, 4 S^{*}, 15 E\right)$-loba-8,10,13(14),15(16)-tetraen-17,18-diol17-acetate (2), and eight known diterpenes: two cembranes, sarcophytol-B [24] and (1E,3E,7E)-11, 12-epoxycembratrien-15-ol [8], and six known lobanes, loba-8,10,13(15)-triene-16,17,18-triol [25], 14,18-epoxyloba-8,10,13(15)-trien-17-ol [26], lobatrientriol [7], lobatrienolide [7], 14,17-epoxyloba-8, 10,13(15)-trien-18-ol-18-acetate [26] and (17R)-loba-8,10,13(15)-trien-17,18-diol [27]. The structural elucidation and biological activities of 1, 2 and of the known compounds loba-8,10,13(15)-triene16,17,18-triol, 14,17-epoxyloba-8,10,13(15)-trien-18-ol-18-acetate, lobatrienolide, $(1 E, 3 E, 7 E)-11$, 12-epoxycembratrien-15-ol and sarcophytol-B against a panel of human tumour cell lines are also presented.

\section{Results and Discussion}

The ${ }^{13} \mathrm{C}$ NMR and ESI-FTMS of 1 established its molecular formula to be $\mathrm{C}_{24} \mathrm{H}_{43} \mathrm{O}_{3} \mathrm{~N}$, requiring four degrees of unsaturation. The ${ }^{1} \mathrm{H}$ and ${ }^{13} \mathrm{C}$ NMR spectral data of $\mathbf{1}$ (Table 1) showed the molecule to contain a trisubstituted double-bond $\left(\delta_{\mathrm{C}} 142.5, \mathrm{~s}, \mathrm{C}-11 ; 117.8, \mathrm{~d}, \mathrm{C}-13 ; \delta_{\mathrm{H}} 5.59, \mathrm{~d}, 5.2, \mathrm{H}-13\right)$ as the only multiple bond within the molecule and accounted for one of the degrees of unsaturation. This information, in combination with the molecular formula, showed the molecule to be tricyclic. 
Table 1. ${ }^{1} \mathrm{H}$ and ${ }^{13} \mathrm{C}$ NMR data $\left(300 \mathrm{MHz}\right.$ and $\left.75 \mathrm{MHz}, \mathrm{CD}_{3} \mathrm{OD}\right)$ for $\left(4 R^{*}, 5 R^{*}, 9 S^{*}\right.$, $\left.10 R^{*}, 11 Z\right)$-4-methoxy-9-((dimethylamino)-methyl)-12,15-epoxy-11(13)-en-decahydrona phthalen-16-ol (1).

\begin{tabular}{|c|c|c|c|c|c|}
\hline No. & ${ }^{13} \mathrm{C} \delta(\mathrm{m})$ & ${ }^{1} \mathrm{H} \delta(\mathrm{m}, J \mathrm{~Hz})$ & COSY & gНМВC & nOe \\
\hline \multirow[t]{2}{*}{1} & $42.3(\mathrm{t})$ & $1.84(1 \mathrm{H}, \mathrm{m})$ & $\mathrm{H}_{\mathrm{b}}-1, \mathrm{H}_{\mathrm{b}}-2$ & C-10, C-5, C-9, C-2, C-3 & \\
\hline & & $1.24(1 \mathrm{H}, \mathrm{m})$ & $\mathrm{H}_{\mathrm{a}}-1, \mathrm{H}_{\mathrm{a}}-2, \mathrm{H}_{\mathrm{b}}-2$ & $\mathrm{C}-5, \mathrm{C}-19, \mathrm{C}-2$ & \\
\hline \multirow[t]{2}{*}{2} & $28.1(\mathrm{t})$ & $1.59(1 \mathrm{H}, \mathrm{m})$ & $\mathrm{H}_{\mathrm{a}}-1, \mathrm{H}_{\mathrm{a}}-3$ & $\mathrm{C}-4$ & \\
\hline & & $1.45(1 \mathrm{H}, \mathrm{m})$ & $\mathrm{H}_{\mathrm{a}}-1$ & $\mathrm{C}-10, \mathrm{C}-1, \mathrm{C}-4$ & \\
\hline \multirow[t]{2}{*}{3} & $36.3(t)$ & $1.85(1 \mathrm{H}, \mathrm{m})$ & $\mathrm{H}_{\mathrm{a}}-2, \mathrm{H}_{\mathrm{b}}-3$ & $C-5, C-1, C-4, C-20$ & \\
\hline & & $1.60(1 \mathrm{H}, \mathrm{m})$ & $\mathrm{H}_{\mathrm{b}}-2, \mathrm{H}_{\mathrm{a}}-3$ & $\mathrm{C}-5, \mathrm{C}-1, \mathrm{C}-4$ & \\
\hline 4 & $76.8(\mathrm{~s})$ & & & & \\
\hline 5 & $53.1(\mathrm{~d})$ & $1.49(1 \mathrm{H}, \mathrm{m})$ & $\mathrm{H}_{2}-6$ & C-6, C-19, C-4, C-20 & \\
\hline 6 & $26.7(\mathrm{t})$ & $1.82(2 \mathrm{H}, \mathrm{m})$ & $\mathrm{H}-5, \mathrm{H}-7$ & C-10, C-8 & \\
\hline 7 & $43.1(\mathrm{~d})$ & $1.86(1 \mathrm{H}, \mathrm{m})$ & $\mathrm{H}_{2}-6$ & C-5, C-8, C-9 & \\
\hline \multirow[t]{2}{*}{8} & $25.0(\mathrm{t})$ & $1.85(1 \mathrm{H}, \mathrm{m})$ & $\mathrm{H}_{\mathrm{b}}-8, \mathrm{H}-9$ & & \\
\hline & & $1.52(1 \mathrm{H}, \mathrm{m})$ & $\mathrm{H}_{\mathrm{a}}-8$ & C-10, C-7, C-22 & \\
\hline 9 & $45.2(\mathrm{~d})$ & $1.52(1 \mathrm{H}, \mathrm{m})$ & $\mathrm{H}_{\mathrm{a}}-22, \mathrm{H}_{\mathrm{b}}-22$ & $\mathrm{C}-10, \mathrm{C}-7, \mathrm{C}-22$ & \\
\hline 10 & $38.0(\mathrm{~s})$ & & & & \\
\hline 11 & $142.5(\mathrm{~s})$ & & & & \\
\hline 12 & $69.0(\mathrm{t})$ & $4.16(2 \mathrm{H}, \mathrm{brs})$ & $\mathrm{H}-13$ & C-7, C-11, C-13, C-15 & \\
\hline 13 & $117.8(\mathrm{~d})$ & $5.59(1 \mathrm{H}, \mathrm{d}, 5.2)$ & $\mathrm{H}-12, \mathrm{H}_{\mathrm{a}}-14, \mathrm{H}_{\mathrm{b}}-14$ & $\mathrm{C}-7, \mathrm{C}-12, \mathrm{C}-14, \mathrm{C}-15$ & \\
\hline \multirow[t]{2}{*}{14} & $26.3(\mathrm{t})$ & $2.12(1 \mathrm{H}, \mathrm{m})$ & $\mathrm{H}-13, \mathrm{H}_{\mathrm{b}}-14, \mathrm{H}-15$ & & \\
\hline & & $2.00(1 \mathrm{H}, \mathrm{m})$ & $\mathrm{H}-13, \mathrm{H}_{\mathrm{a}}-14, \mathrm{H}-15$ & & \\
\hline 15 & 81.9 (d) & $3.25(1 \mathrm{H}, \mathrm{m})$ & $\mathrm{H}_{\mathrm{a}}-14, \mathrm{H}_{\mathrm{b}}-14$ & $\mathrm{C}-17, \mathrm{C}-18$ & \\
\hline 16 & $72.7(\mathrm{~s})$ & & & & \\
\hline 17 & $25.2(\mathrm{q})$ & $1.17(3 \mathrm{H}, \mathrm{s})$ & & C-15, C-16, C-18 & \\
\hline 18 & $25.6(q)$ & $1.17(3 \mathrm{H}, \mathrm{s})$ & & C-15, C-16, C-17 & \\
\hline 19 & $15.2(\mathrm{q})$ & $0.89(3 \mathrm{H}, \mathrm{s})$ & & & $\mathrm{H}_{\mathrm{b}}-1, \mathrm{H}_{\mathrm{b}}-2, \mathrm{H}-20, \mathrm{H}_{2}-22$ \\
\hline 20 & $18.7(q)$ & $1.08(3 \mathrm{H}, \mathrm{s})$ & & C-5, C-4, C-3 & $\mathrm{H}_{\mathrm{b}}-1, \mathrm{H}_{\mathrm{b}}-2, \mathrm{H}-19$ \\
\hline 21 & $48.1(\mathrm{q})$ & $3.16(3 \mathrm{H}, \mathrm{s})$ & & $\mathrm{C}-4$ & H-5 \\
\hline \multirow[t]{2}{*}{22} & $60.5(\mathrm{t})$ & $3.25(1 \mathrm{H}, \mathrm{dd}, 3.2,11.0)$ & $\mathrm{H}-9, \mathrm{H}_{\mathrm{b}}-22$ & C-10, C-8, C-9 & \\
\hline & & $2.93(1 \mathrm{H}, \mathrm{dd}, 11.0,13.1)$ & $\mathrm{H}-9, \mathrm{H}_{\mathrm{a}}-22$ & C-9 & \\
\hline 23 & $45.2(q)$ & $2.90(3 \mathrm{H}, \mathrm{s})$ & & $\mathrm{C}-22, \mathrm{C}-24$ & \\
\hline 24 & $45.2(q)$ & $2.90(3 \mathrm{H}, \mathrm{s})$ & & $\mathrm{C}-22, \mathrm{C}-23$ & \\
\hline
\end{tabular}

From the ${ }^{1} \mathrm{H}^{-1} \mathrm{H}$ COSY spectrum of 1 spin systems from $\mathrm{H}_{\mathrm{b}}-1\left(\delta_{\mathrm{H}} 1.24, \mathrm{~m}\right)$ to $\mathrm{H}_{2}-3\left(\delta_{\mathrm{H}} 1.85, \mathrm{~m}\right.$; $1.60, \mathrm{~m})$ via $\mathrm{H}_{\mathrm{a} / \mathrm{b}}-2\left(\delta_{\mathrm{H}} 1.59, \mathrm{~m} ; 1.45, \mathrm{~m}\right)$ and from $\mathrm{H}-5\left(\delta_{\mathrm{H}} 1.49, \mathrm{~m}\right)$ to $\mathrm{H}_{2}-22\left(\delta_{\mathrm{H}} 3.25, \mathrm{dd}, 3.2,11.0\right.$; 2.93, dd, 11.0, 13.1) via $\mathrm{H}_{2}-6\left(\delta_{\mathrm{H}} 1.82, \mathrm{~m}\right), \mathrm{H}-7\left(\delta_{\mathrm{H}} 1.86 \mathrm{~m}\right), \mathrm{H}_{2}-8\left(\delta_{\mathrm{H}} 1.85, \mathrm{~m} ; 1.52 \mathrm{~m}\right)$ and $\mathrm{H}-9$ $\left(\delta_{\mathrm{H}} 1.52, \mathrm{~m}\right)$ could be discerned. This information together with cross-peaks in the HMBC spectrum from $\mathrm{H}_{\mathrm{b}}-1$ and $\mathrm{H}-5$ to $\mathrm{C}-19\left(\delta_{\mathrm{C}} 15.2, q\right)$, from $\mathrm{H}-20\left(\delta_{\mathrm{H}} 1.08, \mathrm{~s}\right)$ to $\mathrm{C}-3, \mathrm{C}-4$ and $\mathrm{C}-5$, and from $\mathrm{H}-7$ to the olefinic $\mathrm{C}-11\left(\delta_{\mathrm{C}} 142.5, \mathrm{~s}\right)$, showed the presence of a substituted bicyclic ring system.

The ${ }^{1} \mathrm{H}-\mathrm{NMR}$ spectrum of $\mathbf{1}$ displayed singlet resonances of a methoxy $\left(-\mathrm{OCH}_{3}\right)$ at $\delta_{\mathrm{H}} 3.16$ and an $N, N$-dimethyl substituted tertiary amine $\left(-\mathrm{N}\left(\mathrm{CH}_{3}\right)_{2}\right)$ at $\delta_{\mathrm{H}} 2.90$. The $\mathrm{HMBC}$ correlation from $\delta_{\mathrm{H}} 3.16(\mathrm{~s})$ to $\delta_{\mathrm{C}} 76.8$ (s, C-4) located the methoxy at C-4 while correlations from both $\mathrm{H}-23 / 24$ to and $\delta_{\mathrm{C}} 60.5$ (C-22) located the tertiary amine at C-22. 
Further analysis of the ${ }^{1} \mathrm{H}-{ }^{1} \mathrm{H}$ COSY indicated the presence of a spin system from $\delta_{\mathrm{H}} 5.59(\mathrm{~d}, 5.2$, $\mathrm{H}-13)$ to $\delta_{\mathrm{H}} 3.25(\mathrm{~m}, \mathrm{H}-15)$ via $\delta_{\mathrm{H}} 2.12$ and $2.00\left(\mathrm{~m}, \mathrm{H}_{2}-14\right)$. HMBC correlations from $\mathrm{H}-13$ to $\mathrm{C}-7$ located the $\mathrm{C}-11$ side chain at $\mathrm{C}-7$ of the bicyclic ring system. Based on HMBC correlations from $\mathrm{H}_{3}-17 / \mathrm{H}_{3}-18$ to $\delta_{\mathrm{C}} 72.7$ (C-16), the two methyl groups with resonances at $\delta_{\mathrm{H}} 1.17(\mathrm{H}-17 / 18)$ were connected to a tertiary carbon bearing an $\mathrm{OH}$, forming a propan-2-ol-2-yl moiety [28]. The data so far accounted for three of the four oxygens, the double-bond, two of the rings, and the nitrogen, leaving one oxygen and one ring unassigned. An ether linkage, forming the third ring, was deduced between C-12 and C-15 based on the HMBC correlation from $\delta_{\mathrm{H}} 4.16$ (brs, H-12) to $\delta_{\mathrm{C}} 81.9$ (C-15), and was further supported by a C-O-C stretch at $1080 \mathrm{~cm}^{-1}$ in the IR spectrum of 1 . Hence the planar structure of $\mathbf{1}$, a diterpene, is best described as $\left(4 R^{*}, 5 R^{*}, 9 S^{*}, 10 R^{*}, 11 Z\right)-4$-methoxy-9-((dimethylamino)-methyl)-12, 15-epoxy-11(13)-en-decahydronaphthalen-16-ol (Scheme 1).

Scheme 1. Structures of $\left(4 R^{*}, 5 R^{*}, 9 S^{*}, 10 R^{*}, 11 Z\right)$-4-methoxy-9-((dimethylamino)-methyl)12,15-epoxy-11(13)-en-decahydronaphthalen-16-ol (1), and $\left(1 R^{*}, 2 R^{*}, 4 S^{*}, 15 E\right)$-loba-8,10, 13(14),15(16)-tetraen-17,18-diol-17-acetate (2).

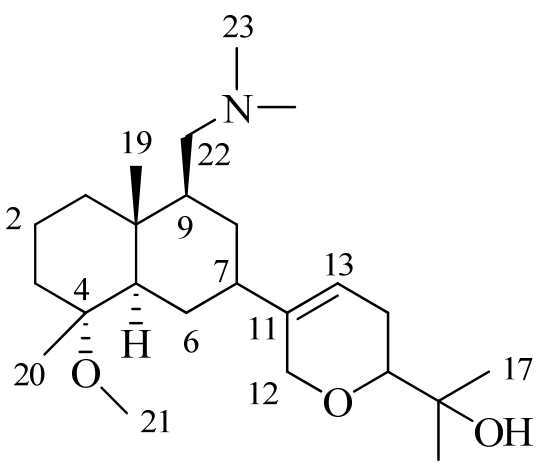

1
18

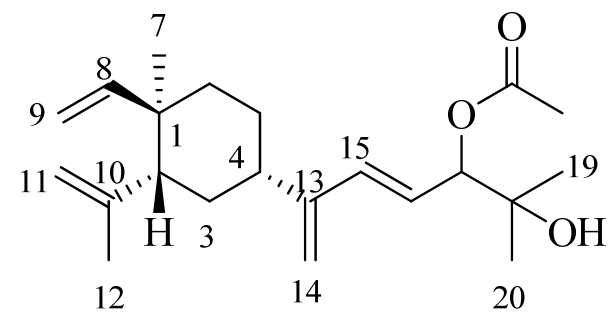

2

The nOe data of 1 showed correlations between $\mathrm{H}_{3}-19\left(\delta_{\mathrm{H}} 0.89\right.$, s) and $\mathrm{H}_{\mathrm{b}}-1, \mathrm{H}_{\mathrm{b}}-2, \mathrm{H}_{3}-20$ and $\mathrm{H}_{\mathrm{b}}-22$. These cross peaks revealed the two fused six-membered rings to have a trans-ring junction, $\mathrm{CH}_{3}-19$ and $\mathrm{CH}_{3}-20$ to be axial and therefore on the same side of 1 , and the side-chain at $\mathrm{C}-9$ to be on the same side as C-19 (Figure 1). Furthermore, nOe correlations were observed between $\mathrm{H}_{3}-21$ and $\mathrm{H}-5$ indicating they were on the same side of the molecule as each other but the opposite side of $\mathrm{C}-19$ (Figure 1). The configurations at C-7 and C-15 remain unresolved. Based on the above findings, the relative configurations of chiral carbons C-10, C-5, C-9 and C-4 of 1 were assigned as $4 R^{*}, 5 R^{*}, 9 S^{*}$ and $10 R^{*}$ (Scheme 1). 
Figure 1. Diagnositic nOe correlations for partial structure of $\mathbf{1}$.

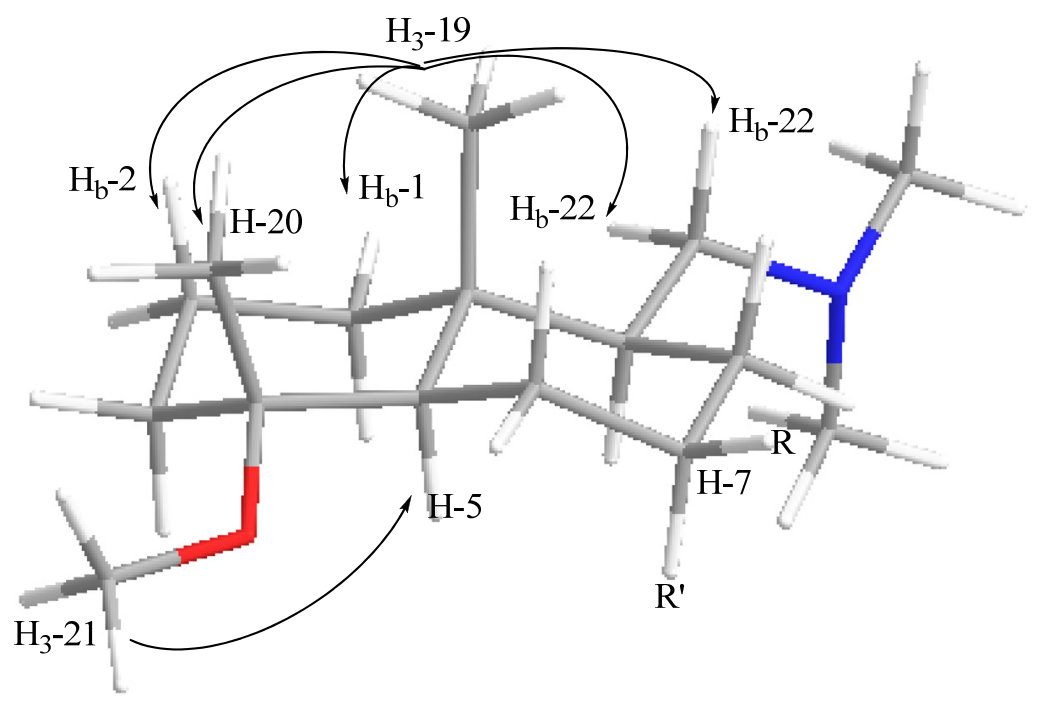

The ${ }^{13} \mathrm{C}$ NMR and ESI-FTMS of 2 established its molecular formula as $\mathrm{C}_{20} \mathrm{H}_{34} \mathrm{O}_{3}$, indicating the molecule to have four degrees of unsaturation. The ${ }^{1} \mathrm{H}$ and ${ }^{13} \mathrm{C}$ NMR spectral data of 2 (Table 2) showed it contained a vinyl moiety $\left(\delta_{\mathrm{C}} 151.6, \mathrm{~d}, \mathrm{C}-8 ; 110.4\right.$, t, C-9; $\delta_{\mathrm{H}} 5.87$, dd, 10.8, $17.6 \mathrm{~Hz}, \mathrm{H}-8$; $\delta_{\mathrm{H}} 4.93, \mathrm{dd}, 1.2,17.6 \mathrm{~Hz}, \mathrm{H}_{\mathrm{a}}-9 ; \delta_{\mathrm{H}} 4.90$, dd, $\left.1.2,10.8 \mathrm{~Hz}, \mathrm{H}_{\mathrm{b}}-9\right)$, an isopropenyl group $\left(\delta_{\mathrm{C}} 148.9, \mathrm{~s}, \mathrm{C}-10\right.$; 112.7, t, C-11, 25.3, q, C-12; $\delta_{\mathrm{H}} 4.81$, brt, $1.5 \mathrm{~Hz}, \mathrm{H}_{\mathrm{a}}-11 ; 4.59$, brs, $\mathrm{H}_{\mathrm{b}}-11 ; 1.71$, brs, $\mathrm{H}_{3}-12$ ) and a tertiary methyl group $\left(\delta_{\mathrm{C}} 17.1, \mathrm{q}, \mathrm{C}-7 ; \delta_{\mathrm{H}} 1.03, \mathrm{~s}, \mathrm{H}_{3}-7\right)$, characteristic of the 3-isopropenyl-4-methyl4-vinylcyclohexane-1-yl moiety found in lobane-type diterpenoids [7,25-27]. This partial structure was confirmed by analysis of the COSY, HMQC, and HMBC NMR spectral data of 2 . The relative configuration about C-1 and C-2 in $\mathbf{2}$ was found to be the same as in elemol and several other lobanes, as established by comparison of the ${ }^{1} \mathrm{H}$ and ${ }^{13} \mathrm{C}$ NMR data for each molecule at centres $\mathrm{C}-1, \mathrm{C}-2, \mathrm{C}-6$, C-7, C-8, C-9, C-10, C-11 and C-12 [25,27]. Also evident from this data was an exo-methylene $\left(\delta_{C} 151.9, \mathrm{~s}, \mathrm{C}-13 ; 114.3, \mathrm{t}, \mathrm{C}-14 ; \delta_{\mathrm{H}} 5.06, \mathrm{~s}, \mathrm{H}_{2}-14\right)$, an endo-disubstituted double-bond $\left(\delta_{C} 137.4, \mathrm{~d}\right.$, C-15; 124.4, d, C-16; $\delta_{\mathrm{H}} 6.26, \mathrm{~d}, 16.0, \mathrm{H}-15 ; 5.78$, dd, 7.6, 16.0, H-16), a carbonyl group in the form of an acetate $\left(\delta_{\mathrm{C}} 172.1, \mathrm{~s}, \mathrm{O}-\mathrm{CO}-\mathrm{CH}_{3} ; 21.1, \mathrm{q} ; \delta_{\mathrm{H}} 2.09, \mathrm{~s}, \mathrm{O}-\mathrm{CO}-\mathrm{CH}_{3}\right)$, a $\mathrm{CH}$ bearing the acetate $\left(\delta_{\mathrm{C}} 82.2\right.$, $\mathrm{d}, \mathrm{C}-17 ; \delta_{\mathrm{H}} 5.14$, brd, 7.6, H-17), and a propan-2-ol-2-yl moiety the same as that found in 1 . These assignments were corroborated by the IR data with terminal vinyl C-H stretches at 3079 and $3012 \mathrm{~cm}^{-1}$, a carbonyl ester band at $1734 \mathrm{~cm}^{-1}$, and an alcohol $\mathrm{OH}$ stretch at $3084 \mathrm{~cm}^{-1}$. This data accounted for all of the remaining unsaturation within the molecule as well as the previously unaccounted for $\mathrm{C}_{10} \mathrm{H}_{15} \mathrm{O}_{3}$. From the HMBC data of 2 (Table 2), it was evident that $\mathrm{C}-17$ bonded to both $\mathrm{C}-15$ and $\mathrm{C}-18$, as well as the oxygen of the acetyl function. Further, HMBC correlations between $\mathrm{H}-14$ and the carbons C-4, C-13 and C-15, confirmed the side-chain to be attached at C-4 and that the two double-bonds were conjugated, an observation supported by the UV maxima of 2 at $227 \mathrm{~nm}$. With the planar structure of 2 deduced, the double-bond geometry and stereochemistry required resolution. The magnitude of the coupling constant between H-15 and H-16 $(J=16.0 \mathrm{~Hz})$, showed $\Delta^{15}$ to have $E$ geometry. The relative configurations at C-1 and C-2 were confirmed to be the same as in the known lobane loba-8,10,13(15)-triene-16,17,18-triol [25] on the basis of comparable ${ }^{13} \mathrm{C}$ NMR chemical shift for the same centres. The relative configurations at C-1, C-2 and C-4 were assigned based on NOESY NMR correlations from $\mathrm{H}-4$ to $\mathrm{H}-2, \mathrm{H}_{2}-5, \mathrm{H}_{\mathrm{a}}-6, \mathrm{H}-14, \mathrm{H}-15, \mathrm{H}-16, \mathrm{H}_{3}-19, \mathrm{H}_{3}-20$ and $\mathrm{O}-\mathrm{CO}-\mathrm{CH}_{3}$, and 
from $\mathrm{H}-12$ to $\mathrm{H}-2, \mathrm{H}_{\mathrm{a}}-6, \mathrm{H}-7, \mathrm{H}-8, \mathrm{H}_{\mathrm{a}}-9, \mathrm{H}_{2}-11, \mathrm{H}_{3}-19$ and confirmed them to be $1 R^{*}, 2 R^{*}$ and $4 S^{*}$, as shown for 2 [6,7,25-27]. The configuration at C-17 remains unresolved. Compound 2 is thus best described as $\left(1 R^{*}, 2 R^{*}, 4 S^{*}, 15 E\right)$-loba-8,10,13(14),15(16)-tetraen-17,18-diol-17-acetate.

Table 2. ${ }^{1} \mathrm{H}$ and ${ }^{13} \mathrm{C} \mathrm{NMR}$ data $\left(300 \mathrm{MHz}\right.$ and $\left.75 \mathrm{MHz}, \mathrm{CD}_{3} \mathrm{OD}\right)$ for $\left(1 R^{*}, 2 R^{*}, 4 S^{*}, 15 E\right)$ loba-8,10,13(14),15(16)-tetraen-17,18-diol-17-acetate (2).

\begin{tabular}{|c|c|c|c|c|c|}
\hline No. & ${ }^{13} \mathrm{C} \delta(\mathrm{m})$ & ${ }^{1} \mathrm{H} \delta(\mathrm{m}, J \mathrm{~Hz})$ & COSY & gНМВС & nOe \\
\hline 1 & $41.0(\mathrm{~s})$ & & & & \\
\hline 2 & $54.1(\mathrm{~d})$ & $2.13(1 \mathrm{H}, \mathrm{m})$ & $\mathrm{H}-3$ & $\begin{array}{l}\text { C-1, C-4, C-7, C-10, } \\
\text { C-11, C-12 }\end{array}$ & $\mathrm{H}-4, \mathrm{H}-12$ \\
\hline 3 & $35.2(\mathrm{t})$ & $1.66(2 \mathrm{H}, \mathrm{m})$ & $\mathrm{H}-2, \mathrm{H}-4$ & $\mathrm{C}-2, \mathrm{C}-4$ & \\
\hline 4 & 41.5 (d) & $\begin{array}{l}2.31(1 \mathrm{H}, \mathrm{tdd}, 3.4,4.2 \text {, } \\
11.7)\end{array}$ & $\mathrm{H}-3, \mathrm{H}_{\mathrm{a}}-5, \mathrm{H}_{\mathrm{b}}-5$ & $\mathrm{C}-3, \mathrm{C}-13, \mathrm{C}-14$ & $\begin{array}{l}\mathrm{H}-2, \mathrm{H}_{\mathrm{a}}-5, \mathrm{H}_{\mathrm{b}}-5, \mathrm{H}_{\mathrm{a}}-6, \\
\text { H-14, H-15, H-16, H-19, } \\
\text { H-20, O-CO-CH }\end{array}$ \\
\hline 5 & $28.8(\mathrm{t})$ & $\begin{array}{l}1.64(1 \mathrm{H}, \mathrm{m}) \\
1.52(1 \mathrm{H}, \mathrm{m})\end{array}$ & $\begin{array}{l}\mathrm{H}-4, \mathrm{H}_{\mathrm{b}}-5, \mathrm{H}_{\mathrm{a}}-6 \\
\mathrm{H}-4, \mathrm{H}_{\mathrm{a}}-5\end{array}$ & $\begin{array}{l}\text { C-3 } \\
\text { C-1, C-4 }\end{array}$ & $\begin{array}{l}\mathrm{H}-4 \\
\mathrm{H}-2, \mathrm{H}-4\end{array}$ \\
\hline 6 & $41.2(\mathrm{t})$ & $\begin{array}{l}1.60(1 \mathrm{H}, \mathrm{m}) \\
1.45(1 \mathrm{H}, \mathrm{m})\end{array}$ & $\begin{array}{l}\mathrm{H}_{\mathrm{a}}-5, \mathrm{H}_{\mathrm{b}}-6 \\
\mathrm{H}_{\mathrm{a}}-6\end{array}$ & $\begin{array}{l}\mathrm{C}-1, \mathrm{C}-2, \mathrm{C}-4, \mathrm{C}-5, \mathrm{C}-7 \\
\mathrm{C}-2, \mathrm{C}-4, \mathrm{C}-5\end{array}$ & H-4, H-12 \\
\hline 7 & $17.1(\mathrm{q})$ & $1.03(3 \mathrm{H}, \mathrm{s})$ & & C-1, C-2, C-6, C-8 & H-12 \\
\hline 8 & $151.6(d)$ & $5.87(1 \mathrm{H}, \mathrm{dd}, 10.8,17.6)$ & $\mathrm{H}_{\mathrm{a}}-9$ & $\mathrm{C}-1, \mathrm{C}-2, \mathrm{C}-6, \mathrm{C}-7$ & $\mathrm{H}-12$ \\
\hline 9 & $110.4(t)$ & $\begin{array}{l}4.93(1 \mathrm{H}, \mathrm{dd}, 1.2 .17 .6) \\
4.90(1 \mathrm{H}, \mathrm{dd}, 1.2,10.8)\end{array}$ & $\begin{array}{l}\mathrm{H}-8, \mathrm{H}_{\mathrm{b}}-9 \\
\mathrm{H}-8, \mathrm{H}_{\mathrm{b}}-9\end{array}$ & $\begin{array}{l}\text { C-1, C-2, C-8 } \\
\text { C-1, C-2, C-8 }\end{array}$ & $\begin{array}{l}\mathrm{H}-12, \mathrm{H}-17 \\
\mathrm{H}-17\end{array}$ \\
\hline 10 & $148.9(\mathrm{~s})$ & & & & \\
\hline 11 & $112.7(\mathrm{t})$ & $\begin{array}{l}4.81(1 \mathrm{H}, \text { brt, } 1.5) \\
4.59(1 \mathrm{H}, \mathrm{brs})\end{array}$ & $\begin{array}{l}\mathrm{H}_{\mathrm{b}}-11, \mathrm{H}_{3}-12 \\
\mathrm{H}_{\mathrm{a}}-11, \mathrm{H}_{3}-12\end{array}$ & $\begin{array}{l}\mathrm{C}-1, \mathrm{C}-2, \mathrm{C}-10, \mathrm{C}-12 \\
\mathrm{C}-1, \mathrm{C}-2, \mathrm{C}-10, \mathrm{C}-12\end{array}$ & $\begin{array}{l}\mathrm{H}-12 \\
\mathrm{H}-12\end{array}$ \\
\hline 12 & $25.3(\mathrm{q})$ & $1.71(3 \mathrm{H}, \mathrm{brs})$ & $\mathrm{H}_{\mathrm{a}}-11, \mathrm{H}_{\mathrm{b}}-11$ & $\mathrm{C}-1, \mathrm{C}-2, \mathrm{C}-10, \mathrm{C}-11$ & $\begin{array}{l}\mathrm{H}-2, \mathrm{H}_{\mathrm{a}}-6, \mathrm{H}-7, \mathrm{H}-8, \\
\mathrm{H}_{\mathrm{a}}-9, \mathrm{H}_{\mathrm{a}}-11, \mathrm{H}_{\mathrm{b}}-11, \mathrm{H}-19\end{array}$ \\
\hline 13 & $151.9(\mathrm{~s})$ & & & & \\
\hline 14 & $114.3(\mathrm{t})$ & $5.06(2 \mathrm{H}, \mathrm{s})$ & & $\mathrm{C}-4, \mathrm{C}-13, \mathrm{C}-15, \mathrm{C}-16$ & $\mathrm{H}-4$ \\
\hline 15 & 137.4(d) & $6.26(1 \mathrm{H}, \mathrm{d}, 16.0)$ & H-16 & $\begin{array}{l}\text { C-4, C-13, C-14, C-16, } \\
\text { C-17 }\end{array}$ & H-4, H-17 \\
\hline 16 & $124.4(d)$ & $5.78(1 \mathrm{H}, \mathrm{dd}, 7.6,16.0)$ & $\mathrm{H}-15, \mathrm{H}-17$ & $\mathrm{C}-13, \mathrm{C}-14, \mathrm{C}-17, \mathrm{C}-18$ & $\mathrm{H}-4, \mathrm{H}-17$ \\
\hline 17 & 82.2 (d) & $5.14(1 \mathrm{H}, \mathrm{brd}, 7.6)$ & $\mathrm{H}-16$ & $\begin{array}{l}\text { C-15, C-16, C-18, C-19, } \\
\text { C-20, O-CO-CH }\end{array}$ & $\begin{array}{l}\mathrm{H}_{\mathrm{a}}-9, \mathrm{H}_{\mathrm{b}}-9, \mathrm{H}-15, \mathrm{H}-16 \\
\mathrm{H}-19, \mathrm{H}-20, \mathrm{O}-\mathrm{CO}-\mathrm{CH}_{3}\end{array}$ \\
\hline 18 & $72.7(\mathrm{~s})$ & & & & \\
\hline 19 & $25.6(\mathrm{q})$ & $1.17(3 \mathrm{H}, \mathrm{s})$ & & $\mathrm{C}-17, \mathrm{C}-18, \mathrm{C}-20$ & $\begin{array}{l}\mathrm{H}-4, \mathrm{H}-12, \mathrm{H}-17 \\
\mathrm{O}-\mathrm{CO}-\mathrm{CH}_{3}\end{array}$ \\
\hline 20 & $26.2(\mathrm{q})$ & $1.18(3 \mathrm{H}, \mathrm{s})$ & & $\mathrm{C}-17, \mathrm{C}-18, \mathrm{C}-19$ & $\mathrm{H}-4, \mathrm{H}-17, \mathrm{O}-\mathrm{CO}-\mathrm{CH}_{3}$ \\
\hline $\mathrm{O}-\mathrm{CO}-\mathrm{CH}_{3}$ & $172.1(\mathrm{~s})$ & & & & \\
\hline $\mathrm{O}-\mathrm{CO}-\mathrm{CH}_{3}$ & $21.1(\mathrm{q})$ & $2.09(3 \mathrm{H}, \mathrm{s})$ & & OAc & $\begin{array}{l}\text { H-4, H-7, H-17, H-19, } \\
\text { H-20 }\end{array}$ \\
\hline
\end{tabular}

Complete 1D and 2D NMR data for the known cembranes: sarcophytol-B and $(1 E, 3 E, 7 E)-11$, 12-epoxycembratrien-15-ol, and the six known lobanes: loba-8,10,13(15)-triene-16,17,18-triol, 14,18-epoxyloba-8,10,13(15)-trien-17-ol, lobatrientriol, lobatrienolide, 14,17-epoxyloba-8,10,13 (15)-trien-18-ol-18-acetate and (17R)-loba-8,10,13(15)-trien-17,18-diol, are provided for the first time 
(Supplementary Information). Raju et al. reported that loba-8,10,13(15)-triene-16,17,18-triol was the product of long-term, cold storage of the natural product 17,18-epoxyloba-8,10,13(15)-trien-16-ol in $\mathrm{CDC}_{3}$ [25]. Closer inspection of the FTMS and ${ }^{13} \mathrm{C}$ NMR of the fresh extract in $\mathrm{CD}_{3} \mathrm{OD}$ showed the presence of only the triol in our study.

The cytotoxic activities of compounds $\mathbf{1}$ and $\mathbf{2}$, and of the known compounds loba-8,10,13 (15)-triene-16,17,18-triol, 14,17-epoxyloba-8,10,13(15)-trien-18-ol-18-acetate, lobatrienolide, (1E,3E, $7 E$ )-11,12-epoxycembratrien-15-ol and sarcophytol-B towards a panel of human tumour cell lines are given in Table 3. With the exception of $\mathbf{1}\left(\mathrm{GI}_{50} \mathrm{~S}\right.$ all over $\left.70 \mu \mathrm{M}\right)$, all compounds showed good activity with $\mathrm{GI}_{50} \mathrm{~s}$ in the range $6.8-18.5 \mu \mathrm{M}$. From these data there appears to be no obvious SAR. The four lobanes (including 2) and the two cembranes all had approximately the same overall activities against the human tumour cell lines SF-268, MCF-7 and H460, with no selectivity.

Table 3. Cytotoxicity data $\left[\mathrm{GI}_{50}(\mu \mathrm{M})\right]$ for compounds $\mathbf{1}, \mathbf{2}$ and the known compounds loba-8,10,13(15)-triene-16,17,18-triol, 14,17-epoxyloba-8,10,13(15)-trien-18-ol-18-acetate, lobatrienolide, (1E,3E,7E)-11,12-epoxycembratrien-15-ol and sarcophytol-B against the human tumour cell lines SF-268, MCF-7 and H460.

\begin{tabular}{cccc}
\hline Compound & SF-268 $^{\mathbf{a}}$ & $\mathbf{M C F - 7}^{\mathbf{b}}$ & $\mathbf{H 4 6 0}^{\mathbf{c}}$ \\
\hline $\mathbf{1}$ & 175 & 70 & 125 \\
$\mathbf{2}$ & 15 & 8.8 & 11.5 \\
Loba-8,10,13(15)-triene-16,17,18-triol & 18.5 & 17 & 13 \\
Lobatrientriol & $\mathrm{NT}$ & $\mathrm{NT}$ & $\mathrm{NT}$ \\
Lobatrienolide & 14 & 16 & 18.5 \\
14,17-Epoxyloba-8,10,13(15)-trien-18-ol-18-acetate & 7.4 & 17 & 18 \\
14,18-Epoxyloba-8,10,13(15)-trien-17-ol & $\mathrm{NT}$ & $\mathrm{NT}$ & $\mathrm{NT}$ \\
$(17 R)$-Loba-8,10,13(15)-trien-17,18-diol & $\mathrm{NT}$ & $\mathrm{NT}$ & $\mathrm{NT}$ \\
$(1 E, 3 E, 7 E)-11,12-$-Epoxycembratrien-15-ol & 6.8 & 12 & 18.5 \\
Sarcophytol-B & 16 & 12.5 & 15 \\
\hline
\end{tabular}

${ }^{\mathrm{a}}$ SF-268 Central nervous system-glioblastoma cells; ${ }^{\mathrm{b}} \mathrm{MCF}-7$ Breast-pleural effusion adenocarcinoma cells;

${ }^{\mathrm{c}}$ H460 Lung-large cell carcinoma cells; NT = Not tested.

\section{Experimental Section}

\subsection{General Experimental Procedures}

General experimental procedures are as described previously [29].

\subsection{Animal Material}

The soft coral Sinularia sp., (Order Alcyonacea, Family Alcyoniidae) was collected from the eastern edge of the lagoon at Bowden Reef $\left(19^{\circ} 2.1^{\prime} \mathrm{S}, 147^{\circ} 56.0^{\prime} \mathrm{E}\right)$ in the Central Great Barrier Reef, Queensland, Australia, at a depth of $9 \mathrm{~m}$, in June 2005. Collection of this material was conducted under the GBRMPA Permit no. G05/11866.1 and kept frozen $\left(-20^{\circ} \mathrm{C}\right)$ until work-up. A voucher specimen (AIMS 27026) has been lodged with the AIMS Bioresources Library. 


\subsection{Bioassay}

Cellular bioassays were undertaken as described previously [29].

\subsection{Extraction and Isolation}

Freeze dried animal material (29.6 g) was extracted with $\mathrm{MeOH}(3 \times 400 \mathrm{~mL})$ and a butanol: $\mathrm{CH}_{2} \mathrm{Cl}_{2}: \mathrm{H}_{2} \mathrm{O}(150: 50: 100 \mathrm{~mL})$ partition performed. The aqueous phase was further partitioned with $\mathrm{BuOH}: \mathrm{CH}_{2} \mathrm{Cl}_{2}(150: 50 \mathrm{~mL})$ and the organic phase added to the first organic fraction. The organic fraction (16.8 $\mathrm{g}$ ) was then subjected to reversed phase $\mathrm{C} 18$ flash vacuum chromatography (RP-C18, $25 \%, 50 \%, 75 \%, 100 \% \mathrm{MeOH}$ in $\mathrm{H}_{2} \mathrm{O}$ and $\left.1: 1 \mathrm{MeOH}: \mathrm{CH}_{2} \mathrm{Cl}_{2}\right)$. Activity was observed for the first four fractions. A portion of the $25 \% \mathrm{MeOH}$ fraction $(3.44 \mathrm{~g}$ of $10.27 \mathrm{~g}$ ) was pre-absorbed onto $\mathrm{C} 18$, packed into a cartridge, and further separated by preparative C18 HPLC ( $52 \mathrm{~mL} / \mathrm{min}$, isocratic elution at $15 \% \mathrm{CH}_{3} \mathrm{CN}: \mathrm{H}_{2} \mathrm{O}$ for $3 \mathrm{~min}$ followed by gradient elution from $15 \% \mathrm{CH}_{3} \mathrm{CN}: \mathrm{H}_{2} \mathrm{O}$ to $100 \%$ $\mathrm{CH}_{3} \mathrm{CN}: \mathrm{H}_{2} \mathrm{O}$ over $50 \mathrm{~min}$ and an isocratic elution at $100 \% \mathrm{CH}_{3} \mathrm{CN}$ for $30 \mathrm{~min}$ through a $250 \times 41.1 \mathrm{~mm}$ Varian Dynamax Microsorb 60-8 C18 column), fractions were collected every $30 \mathrm{~s}(n=176)$ to yield (in order of elution) $\left(4 R^{*}, 5 R^{*}, 9 S^{*}, 10 R^{*}, 11 Z\right)$-4-methoxy-9-((dimethylamino)-methyl)-12,15-epoxy-11 (13)-en-decahydronaphthalen-16-ol (1, fr 19 and 20 combined, $18.3 \mathrm{mg}, 0.06 \%$ dry wt of extract), lobatrientriol [7] (fr 71, $24.6 \mathrm{mg}, 0.08 \%$ dry wt of extract), loba-8,10,13(15)-triene-16,17,18-triol (fr $81,21.1 \mathrm{mg}, 0.07 \%$ dry wt of extract), 14,17-epoxyloba-8,10,13(15)-trien-18-ol-18-acetate [26] (fr, 83 and 84 combined, $72.8 \mathrm{mg}, 0.07 \%$ dry wt of extract), lobatrienolide [7] (fr 87, $24.9 \mathrm{mg}, 0.08 \%$ dry wt of extract), (1E,3E,7E)-11,12-epoxycembratrien-15-ol [8] (fr $89,30.9 \mathrm{mg}, 0.10 \%$ dry wt of extract) and 14,18-epoxyloba-8,10,13(15)-trien-17-ol [26] (fr 109, $123.7 \mathrm{mg}, 0.42 \%$ dry wt of extract). Fractions 100 to 102 were combined $(108.4 \mathrm{mg})$ and further purified by $\mathrm{C} 18$ analytical HPLC ( $1 \mathrm{~mL} / \mathrm{min}$, gradient elution from $5 \% \mathrm{CH}_{3} \mathrm{CN}: \mathrm{H}_{2} \mathrm{O}$ to $100 \% \mathrm{CH}_{3} \mathrm{CN}$ over $18 \mathrm{~min}$, followed by $6 \mathrm{~min}$ with $100 \% \mathrm{CH}_{3} \mathrm{CN}$ through $250 \times 4.6 \mathrm{~mm}, 5 \mu$ Phenomenex Luna (2) $\mathrm{C} 18$ column and fractions collected every $30 \mathrm{~s}$ ) to yield the known compounds (17R)-loba-8,10,13(15)-triene-17,18-diol [27] (fr 34, $6.2 \mathrm{mg}, 0.02 \%$ dry wt of extract) and sarcophytol-B [24] (fr 36, $18.3 \mathrm{mg}, 0.06 \%$ dry wt of extract) and the new compound $\left(1 R^{*}, 2 R^{*}, 4 S^{*}, 15 E\right)$-loba-8,10,13(14),15(16)-tetraen-17,18-diol-17-acetate (2, fr 33, $2.3 \mathrm{mg}, 0.008 \%$ dry wt of extract). The known compounds had identical physical and spectroscopic properties to those previously published [7,8,24,26,27].

\subsection{1. ( $\left.4 R^{*}, 5 R^{*}, 9 S^{*}, 10 R^{*}, 11 Z\right)-4$-Methoxy-9-((dimethylamino)-methyl)-12,15-epoxy-11}

(13)-en-decahydronaphthalen-16-ol (1)

Pale yellow oil. $[\alpha]^{24}+72^{\circ}\left(\mathrm{CH}_{3} \mathrm{OH} ; c\right.$ 0.67); UV (PDA) $\lambda_{\max } \mathrm{nm}: 195,208$; IR $v_{\max } \mathrm{cm}^{-1}: 3388$, 2969, 2935, 1645, 1468, 1384, 1161, 1080; ${ }^{1} \mathrm{H}\left(300 \mathrm{MHz}, \mathrm{CD}_{3} \mathrm{OD}\right)$ and ${ }^{13} \mathrm{C}\left(75 \mathrm{MHz}, \mathrm{CD}_{3} \mathrm{OD}\right) \mathrm{NMR}$ data Table 1; ESI-FTMS m/z $[\mathrm{M}+\mathrm{H}]^{+} 394.3316$ (calcd for $\mathrm{C}_{24} \mathrm{H}_{44} \mathrm{O}_{3} \mathrm{~N}$ 394.3303), $[\mathrm{M}+\mathrm{Na}]^{+}$ 416.3128 (calcd for $\mathrm{C}_{24} \mathrm{H}_{43} \mathrm{O}_{3} \mathrm{NNa} 416.3135$ ). 
3.4.2. $\left(1 R^{*}, 2 R^{*}, 4 S^{*}, 15 E\right)$-Loba-8,10,13(14),15(16)-tetraen-17,18-diol-17-acetate (2)

Colourless oil. $[\alpha]_{D}^{24}-9.5^{\circ}\left(\mathrm{CH}_{3} \mathrm{OH} ; c\right.$ 0.23); UV (PDA) $\lambda_{\max } \mathrm{nm}: 203,227$; IR $v_{\max } \mathrm{cm}^{-1}: 3408$, 2963, 2926, 1734, 1635, 1455, 1372, 1234, 1024, 904; ${ }^{1} \mathrm{H}\left(300 \mathrm{MHz}, \mathrm{CD}_{3} \mathrm{OD}\right)$ and ${ }^{13} \mathrm{C}(75 \mathrm{MHz}$, $\mathrm{CD}_{3} \mathrm{OD}$ ) NMR data Table 2; ESI-FTMS $m / z[\mathrm{M}+\mathrm{Na}]^{+} 369.2396$ (calcd for $\mathrm{C}_{22} \mathrm{H}_{34} \mathrm{O}_{3} \mathrm{Na} 369.2400$ ).

\subsubsection{Loba-8,10,13(15)-triene-16,17,18-triol}

Colourless oil. ${ }^{1} \mathrm{H}-\mathrm{NMR}$ and ${ }^{13} \mathrm{C}-\mathrm{NMR}$ spectral data were consistent with published values [25]; ESI-FTMS $m / z[\mathrm{M}+\mathrm{Na}]^{+} 345.2398$ (calcd for $\mathrm{C}_{20} \mathrm{H}_{34} \mathrm{O}_{3} \mathrm{Na} 345.2400$ ).

\subsubsection{Lobatrientriol}

Colourless oil. ${ }^{1} \mathrm{H}-\mathrm{NMR}$ and ${ }^{13} \mathrm{C}-\mathrm{NMR}$ spectral data were consistent with published values [7].

3.4.5. 14,17-Epoxyloba-8,10,13(15)-trien-18-ol-18-acetate

Colourless oil. ${ }^{1} \mathrm{H}-\mathrm{NMR}$ and ${ }^{13} \mathrm{C}-\mathrm{NMR}$ spectral data were consistent with published values [26].

\subsubsection{Lobatrienolide}

Colourless oil. ${ }^{1} \mathrm{H}-\mathrm{NMR}$ and ${ }^{13} \mathrm{C}-\mathrm{NMR}$ spectral data were consistent with published values [7].

3.4.7. (1E,3E,7E)-11,12-Epoxycembratrien-15-ol

Colourless oil. ${ }^{1} \mathrm{H}-\mathrm{NMR}$ and ${ }^{13} \mathrm{C}-\mathrm{NMR}$ spectral data were consistent with published values [8].

3.4.8. 14,18-Epoxyloba-8,10,13(15)-trien-17-ol

Colourless oil. ${ }^{1} \mathrm{H}-\mathrm{NMR}$ and ${ }^{13} \mathrm{C}-\mathrm{NMR}$ spectral data were consistent with published values [26].

3.4.9. (17R)-Loba-8,10,13(15)-trien-17,18-diol

Colourless oil. ${ }^{1} \mathrm{H}-\mathrm{NMR}$ and ${ }^{13} \mathrm{C}-\mathrm{NMR}$ spectral data were consistent with published values [27].

3.4.10. Sarcophytol-B

Colourless oil. ${ }^{1} \mathrm{H}-\mathrm{NMR}$ and ${ }^{13} \mathrm{C}-\mathrm{NMR}$ spectral data were consistent with published values [24].

\section{Conclusion}

Two new compounds, the somewhat unprecedented nitrogen containing $\left(4 R^{*}, 5 R^{*}, 9 S^{*}, 10 R^{*}, 11 Z\right)$ 4-methoxy-9-((dimethylamino)-methyl)-12,15-epoxy-11(13)-en-decahydronaphthalen-16-ol (1) and the lobane $\left(1 R^{*}, 2 R^{*}, 4 S^{*}, 15 E\right)$-loba-8,10,13(14),15(16)-tetraen-17,18-diol-17-acetate (2), together with the eight known compounds sarcophytol-B [24], (1E,3E,7E)-11,12-epoxycembratrien-15-ol [8], loba-8,10,13(15)-triene-16,17,18-triol [25], 14,18-epoxyloba-8,10,13(15)-trien-17-ol [26], lobatrientriol [7], lobatrienolide [7], 14,17-epoxyloba-8,10,13(15)-trien-18-ol-18-acetate [26] and 
(17R)-loba-8,10,13(15)-trien-17,18-diol [27], were isolated from the Australian soft coral Sinularia sp. Although there are many publications detailing the isolation of lobanes [6,7] and cembranes [8,9,11] from soft corals of the genus Sinularia, this report shows that new investigations are still yielding further new and somewhat unprecedented derivatives, and that continued investigations of this genus are warranted. The biological and pharmacological properties associated with soft coral chemistry, in particular terpenoids, have been shown to be highly promising [30], leading to the need for more extensive structure-activity relationship studies and further evaluation of their mechanism of action.

\section{Acknowledgements}

Collection of this soft coral was made possible through the access and benefit sharing arrangements between AIMS and the Australian Commonwealth Government. The authors are grateful to those AIMS staff, both past and present, involved in the collection. We thank A.-M. Babey, School of Veterinary and Biomedical Sciences, James Cook University for initial cytotoxicity screening data and for the SF-268 cell line and C. Hooi, R. Anderson and C. Cullinane, of the Peter MacCallum Cancer Centre, Melbourne, Australia, for the MCF-7 and H460 cell lines.

\section{References}

1. Bowden, B.F.; Coll, J.C.; de Silva, E.D.; de Costa, M.S.L.; Djura, P.J.; Mahendran, M.; Tapiolas, D.M. Studies of Australian soft corals. XXXI. Novel furanosesquiterpenes from several sinularian soft corals (Coelenterata, Octocorallia, Alcyonacea). Aust. J. Chem. 1983, 36, 371-376.

2. Park, S.K.; Scheuer, P.J. Isolation and structure determination of two furanosesquiterpenes from the soft coral Sinularia lochmodes. J. Korean Chem. Soc. 1994, 38, 749-752.

3. Radwan, M.M.; Manly, S.P.; Sayed, K.A.E.; Wali, V.B.; Sylvester, P.W.; Awate, B.; Shah, G.; Ross, S.A. Sinulodurins A and B, antiproliferative and anti-invasive diterpenes from the soft coral Sinularia dura. J. Nat. Prod. 2008, 71, 1468-1471.

4. Cheng, S.-Y.; Chuang, C.-T.; Wang, S.-K.; Wen, Z.-H.; Chiou, S.-F.; Hsu, C.-H.; Dai, C.-F.; Duh, C.-Y. Antiviral and anti-inflammatory diterpenoids from the soft coral Sinularia gyrosa. J. Nat. Prod. 2010, 73, 1184-1187.

5. Aceret, T.L.; Coll, J.C.; Uchio, Y.; Sammarco, P.W. Antimicrobial activity of the diterpenes flexibilide and sinulariolide derived from Sinularia flexibilis Quoy and Gaimard 1833 (Coelenterata: Alcyonacea, Octocorallia). Comp. Biochem. Physiol. Part C 1998, 120, 121-126.

6. Chai, M.-C.; Wang, S.-K.; Dai, C.-F.; Duh, C.-Y. A cytotoxic lobane diterpene from the Formosan soft coral Sinularia inelegans. J. Nat. Prod. 2000, 63, 843-844.

7. Hamada, T.; Kusumi, T.; Ishitsuka, M.O.; Kakisawa, H. Structures and absolute configurations of new lobane diterpenoids from the Okinawan soft coral Sinularia flexibilis. Chem. Lett. 1992, 21, 33-36.

8. Duh, C.-Y.; Hou, R.-S. Cytotoxic cembranoids from the soft corals Sinularia gibberosa and Sarcophyton trocheliophorum. J. Nat. Prod. 1996, 59, 595-598.

9. Duh, C.-Y.; Wang, S.-K.; Tseng, H.-K.; Sheu, J.-H.; Chiang, M.Y. Novel cytotoxic cembranoids from the soft coral Sinularia flexibilis. J. Nat. Prod. 1998, 61, 844-847. 
10. Su, J.-H.; Ahmed, A.F.; Sung, P.-J.; Chao, C.-H.; Kuo, Y.-H.; Sheu, J.-H. Manaarenolides A-I, diterpenoids from the soft coral Sinularia manaarensis. J. Nat. Prod. 2006, 69, 1134-1139.

11. Lu, Y.; Huang, C.-Y.; Lin, Y.-F.; Wen, Z.-H.; Su, J.-H.; Kuo, Y.-H.; Chiang, M.Y.; Sheu, J.-H. Anti-inflammatory cembranoids from the soft corals Sinularia querciformis and Sinularia granosa. J. Nat. Prod. 2008, 71, 1754-1759.

12. Jagodzinska, B.M.; Trimmer, J.S.; Fenical, W.; Djerassi, C. Sterols in marine invertebrates. 51: Isolation and structure elucidation of C-18 functionalized sterols from the soft coral Sinularia dissecta. J. Org. Chem. 1985, 50, 2988-2992.

13. Kumar, R.; Lakshmi, V. Two new glycosides from the soft coral Sinularia firma. Chem. Pharm. Bull. 2006, 54, 1650-1652.

14. Subrahmanyam, C.; Kulatheeswaran, R.; Rao, C.V. New sphingosines from two soft corals of the Andaman and Nicobar islands. Indian J. Chem. Sec. B 1996, 35, 578-580.

15. Cheng, S.-Y.; Huang, K.-J.; Wang, S.-K.; Duh, C.-Y. Capilloquinol: A novel farnesyl quinol from the Dongsha Atoll soft coral Sinularia capillosa. Mar. Drugs 2011, 9, 1469-1476.

16. Coll, J.C.; Liyanage, N.; Stokie, G.J.; Van Altena, I.; Nemorin, J.N.E.; Sternhell, S.; Kazlauskas, R. Studies of Australian soft corals. III. A novel furanoquinol from Sinularia lochmodes. Aust. J. Chem. 1978, 31, 157-162.

17. Ojika, M.; Islam, M.K.; Shintani, T.; Zhang, Y.; Okamoto, T.; Sakagami, Y. Three new cytotoxic acylspermidines from the soft coral, Sinularia sp. Biosci. Biotechnol. Biochem. 2003, 67, 1410-1412.

18. Arepalli, S.K.; Sridhar, V.; Rao, J.V.; Kennady, P.K.; Venkateswarlu, Y. Furano-sesquiterpene from soft coral, Sinularia kavarittiensis: induces apoptosis via the mitochondrial-mediated caspase-dependent pathway in THP-1, leukemia cell line. Apotosis 2009, 14, 729-740.

19. Mizobuchi, S.; Kon-ya, K.; Adachi, K.; Sakai, M.; Miki, W. Antifouling substances from a Palauan octocoral Sinularia sp. Fish. Sci. 1994, 60, 345-346.

20. Slattery, M.; Hines, G.A.; Starmer, J.; Paul, V.J. Chemical signals in gametogenesis, spawning, and larval settlement and defense of the soft coral Sinularia polydactyla. Coral Reefs 1999, 18, $75-84$.

21. Sammarco, P.W.; Coll, J.C.; Barre, S.; Willis, B. Competitive strategies of soft corals (Coelenterata: Octocorallia): Allelopathic effects on selected scleractinian corals. Coral Reefs 1983, 1, 173-178.

22. Coll, J.C.; Bowden, B.F.; Heaton, A.; Scheuer, P.J.; Li, M.K.W.; Clardy, J.; K., S.G.; Finer-Moore, J. Structures and possible functions of epoxypukalide and pukalide diterpenes associated with eggs of sinularian soft corals (Cnidaria, Anthozoa, Octocorallia, Alcyonacea, Alcyoniidae). J. Chem. Ecol. 1989, 15, 1177-1191.

23. Boyd, M.R. The NCI in-vitro anticancer drug discovery screen: Concept, implementation and operation, 1985-1995. In Anticancer Drug Development Guide: Preclinical Screening, Clinical Trials, and Approval; Teicher, B.A., Ed.; Humana Press: Totowa, NJ, USA, 1997; pp. 23-42.

24. Kobayashi, M.; Nakagawa, T.; Mitsuhashi, H. Marine terpenes and terpenoids I: Structures of four cembrane-type diterpenes; from the soft coral Sarcophyton glaucum. Chem. Pharm. Bull. 1979, 27, 2382-2387.

25. Raju, B.L.; Subbaraju, G.V.; Rao, C.B.; Trimurtulu, G. Two new oxygenated lobanes from a soft coral of Lobophytum species of the Andaman and Nicobar coasts. J. Nat. Prod. 1993, 56, 961-966. 
26. Edrada, R.A.; Proksch, P.; Wray, V.; Witte, L.; van Ofwegen, L. Four new bioactive lobane diterpenes of the soft coral Lobophytum pauciflorum from Mindoro, Philippines. J. Nat. Prod. 1998, 61, 358-361.

27. Dunlop, R.W.; Wells, R. Isolation of some novel diterpenes from a soft coral of the genus Lobophytum. Aust. J. Chem. 1979, 32, 1345-1351.

28. Trimurtulu, G.; Faulkner, D.J. Six new diterpene isonitriles from the sponge Acanthella cavernosa. J. Nat. Prod. 1994, 57, 501-506.

29. Ovenden, S.P.B.; Nielson, J.L.; Liptrot, C.H.; Willis, R.H.; Wright, A.D.; Motti, C.A.; Tapiolas, D.M. Comosusols A-D and comosone A: Cytotoxic compounds from the brown alga Sporochnus comosus. J. Nat. Prod. 2011, 74, 739-743.

30. Kamel, H.N.; Slattery, M. Terpenoids of Sinularia: Chemistry and biomedical applications. Pharm. Biol. 2005, 43, 253-269.

Samples Availability: Available from the authors.

(C) 2012 by the authors; licensee MDPI, Basel, Switzerland. This article is an open access article distributed under the terms and conditions of the Creative Commons Attribution license (http://creativecommons.org/licenses/by/3.0/). 